ISSN: 2362-1303 (Paper) | eISSN: 2362-1311(Online)

JOURNAL OF ADVANCED ACADEMIC RESEARCH (JAAR)

October 2016

\title{
Relationship between study habits and achievements of grade ten students in Nepal
}

\author{
Tek Narayan Poudel \\ PhD Scholar, Mewar University
}

\begin{abstract}
The study environment can have a big effect on the overall performance of students. Factors such as noise, interruptions, lighting, temperature, neatness, comfort and equipment can play a major role in shaping the performance of the student. Study habit involves different kinds of personality traits, attitudes, thinking processes, and behaviors related to how a person approaches a learning task. Improving study skills likely involves changing some habits, and making a conscious decision to do so. It is essential to assess the current study habits and its effect on the achievement of students. The study was conducted among the 511 grade ten students of three districts of Nepal. It shows very weak effect of study habit on performance of student. Regression analysis between the study habit and achievement shows that study habit could explain only 2\%-8\% variation on achievement of students so it indicates the need of improvement in study habit. Proper orientation of study habit is not adequate among the management, teacher, guardians and students so it should be taken serious by concerned person to improve the effectiveness of study habit.
\end{abstract}

\section{KEYWORDS}

Achievements, Nepal, Practices, Student, Study Habits

\section{INTRODUCTION}

The study habit is one of the major indicators of successful achievement of students. Either theoretically or practically, it is well proved that the laborious students get the remarkable achievement in exam or other extra activities. The study has administered the eight types of standard scale to measure the study habit; Time Management, Concentration, Note Taking, Reading Understanding, Test Preparation and Test Taking, Reading Speed, Writing Skills and Test Anxiety Management.

Many studies show that study habit has a direct relationship with the academic achievement. Patmalnice (2011) explains that it is no longer questioned that high education level and human capital formation promote human well-being and are two of the main predictors for economic growth (Patmalniece, 2011). Low significant correlations were observed between academic achievement and educational aspirations and occupational aspiration. Students may not know the academic requirements needed for the highest level of education and type of occupations they aspired (MOHAMED, 2004). The effect of social background on educational achievement 
are well documented. Empirical data show that children from higher socio-economic backgrounds perform better at school and choose longer courses of study than their counterparts from lower backgrounds (Lionel Page, 2006). The nutrition education of school children can bring about change in their dietary behavior, which sometimes last for over 2 years (Worsley, 2002). Study habits typically denotes the degree to which the student engages in regular acts of studying that are characterized by appropriate studying routines (e.g., reviews of material) occurring in an environment that is conducive to studying. Study attitudes is usually used to refer to a student's positive attitude toward the specific act of studying and the student's acceptance and approval of the broader goals of a college education (Kuncel, 2008)

In a study carried out by Olatoye, he found out that the study skills of the high school students very poor. Poor performance in school have been traced to poor study habit. He noted that if study skills are not improved, students will continue to perform poorly in tests and may not be able to realize their full potential. Students should therefore evolve good study habit skills like note-taking, time management, organizing for a test, recording regular assignments in a notebook, having regular time to study while removing distractions that come from television or phone call at home (Olatoye, 2009). Performance of student is the concerned of school, teacher, parents and even of students. There are various causes which affect the learning and achievement of students; one of them is study habit. Study habit is one important cause to determine the student performance so the study main aim is to explore the relationship between the study habit and achievement of grade ten student of Nepal.

\section{METHODOLOGY}

The study was conducted in Kaski, Syangja and Parbat district based on the descriptive research design which described the practices and association between study habits and achievements of class ten students of Nepal. The study had collected the quantitative data by using the structured survey questionnaires. The random sampling technique was used to select the students from selected districts of Nepal. All total 511 respondents were selected from the both public and private schools. The method of statistical analysis of data was completed by using the SPSS. The regression analysis was done to find out the effect of study habit on academic achievements.

\section{RESULT AND DISCUSSION}

The study had analysed the variance of mean of different variables on the basis of districts. Total 511 students from the Kaski, Syangja and Parbat districts had participated in the study students.

\section{Study habit and position of student in class}

From the analysis of linear regression, it is found that the $\mathrm{R}^{2}$ value is .044 which means that the study variables (Time Management - TM, concentration, Note Taking - NT, Reading 
Understanding - RU, Test Preparation and Test Taking - TP, Reading Speed - RS, Writing Skills - WR, Test Anxiety Management - TAM) only explain 4\% of the variation in the position of students in school (dependent variable).

The adjusted $\mathrm{R}^{2}$ value is .028 which means that the different study habit contributed only $2 \%$ in determining the position of students. The remaining $98 \%$ were contributed by other factors which are not included in this study.

Table 1: Regression analysis of study habit and position of student in class

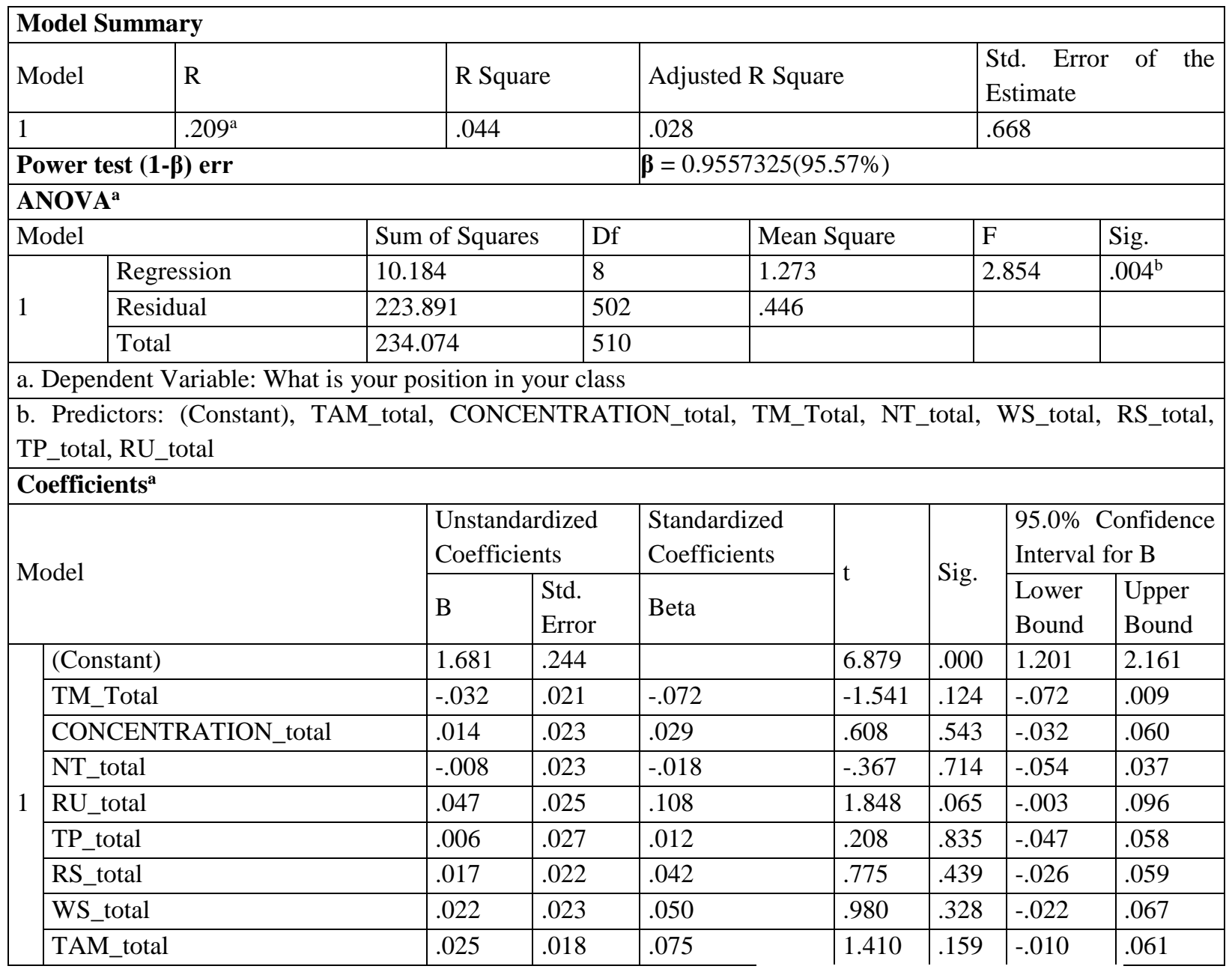

Source: field survey 2014.

The regression analysis on all variables of study habit were found significant at $\mathrm{p} \leq 0.05$ (.004), at $\mathrm{F}=2.854$ to determine the position of students in class room. However, there were no significant difference on all types of study habit (Time management, concentration, Note Taking, Reading Understanding, Test Preparation and Test Taking, Reading Speed, Writing Skills, Test Anxiety 
Management) with position of students that the p-value of each was $.124, .543, .714, .065, .835$, $.439, .328$ and .159 respectively.

The study found that there was no expected effect of study habit on the achievement of students. The study also explored the reasons through the in-depth interview with students regarding their study habit. The study found that there was no fixed schedule of study time among the majority of students. If student has no proper schedule of study then it might effect in their effective learning. The findings of qualitative discussed gave the ideas that there was no systematic study habit of students so that also there was no expected effect of study habit in their academic achievements.

\section{Study habit and expected position of student in SLC result}

The study had also analyzed the data to know the relationship between the study habit and achievement of students.

Table 2: Regression analysis of study habit and expected position of student in SLC result

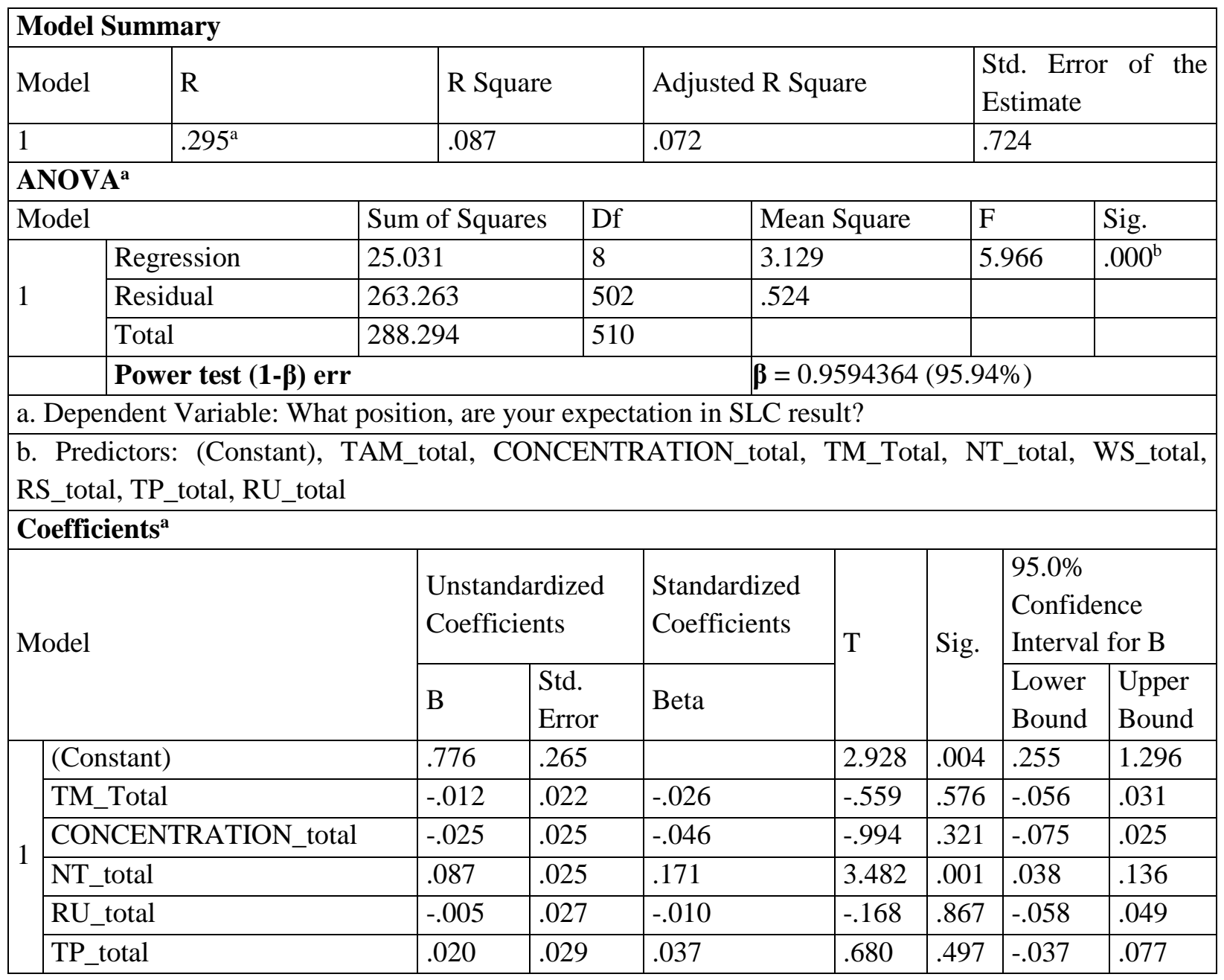




\begin{tabular}{|l|l|l|l|l|l|l|l|l|}
\hline RS_total & .063 & .023 & .143 & 2.671 & .008 & .017 & .109 \\
\hline WS_total & .047 & .025 & .096 & 1.927 & .055 & -.001 & .096 \\
\hline TAM_total & -.001 & .020 & -.003 & -.064 & .949 & -.040 & .037 \\
\hline
\end{tabular}

Source: field survey 2014.

In this connection, the study did the linear regression; it is found that the $\mathrm{R}^{2}$ value is .087 which means that the study variables (Time management, concentration, Note Taking, Reading Understanding, Test Preparation and Test Taking, Reading Speed, Writing Skills, Test Anxiety Management) only explain $8 \%$ of the variation in the expected position of students in SCL result (dependent variable). The adjusted $\mathrm{R}^{2}$ value is .072 which means that the different study habit contributed only 7\% in expected position of students in SLC result. The remaining 93\% were contributed by other factors which are necessary to explore from the further study.

The contribution of study habit found very weak in the context of this study districts. The reason was environmental factors. More than $80 \%$ students reported that schools' and home's environment could effect in their learning and achievements. They suggested improving the study environment also.

The regression analysis on all eight types of study habits were found significant at $\mathrm{p} \leq 0.05$ (.000), at $\mathrm{F}=5.966$ to expected position of students in SLC result. However, it was found out that only three variables were significant which had $p$-value $\leq 0.05$, namely note taking, reading speed and writing skills. Rest five variables i.e. time management, concentration, Reading Understanding, Test Preparation and Test Taking, and Test Anxiety Management were not significant with expected position of students in SLC result since the p-value of each was .576, $.321, .867, .497$ and .949 respectively. We may conclude by saying that at least three types of study habits, namely note taking, reading speed and writing skills had impact on the expected position of students in SLC result.

\section{Study habit and participation in quiz content}

The study had also analyzed the data to know the relationship between the study habit and participation in quiz content of students. In this connection, the study did the linear regression; it is found that the $\mathrm{R}^{2}$ value is .032 which means that the study variables (Time management, concentration, Note Taking, Reading Understanding, Test Preparation and Test Taking, Reading Speed, Writing Skills, Test Anxiety Management) only explain 3\% of the variation in the practice of participation in quiz content of students (dependent variable). The adjusted $\mathrm{R}^{2}$ value is .017 which means that the different study habit contributed only $1 \%$ in the practice of students in participating in quiz content. The remaining $99 \%$ were contributed by other factors which are necessary to explore from the further study.

Table 3: Regression analysis of study habit and participation in quiz content

Model Summary 
ISSN: 2362-1303 (Paper) | elSSN: 2362-1311(Online)

JOURNAL OF ADVANCED ACADEMIC RESEARCH (JAAR)

October 2016

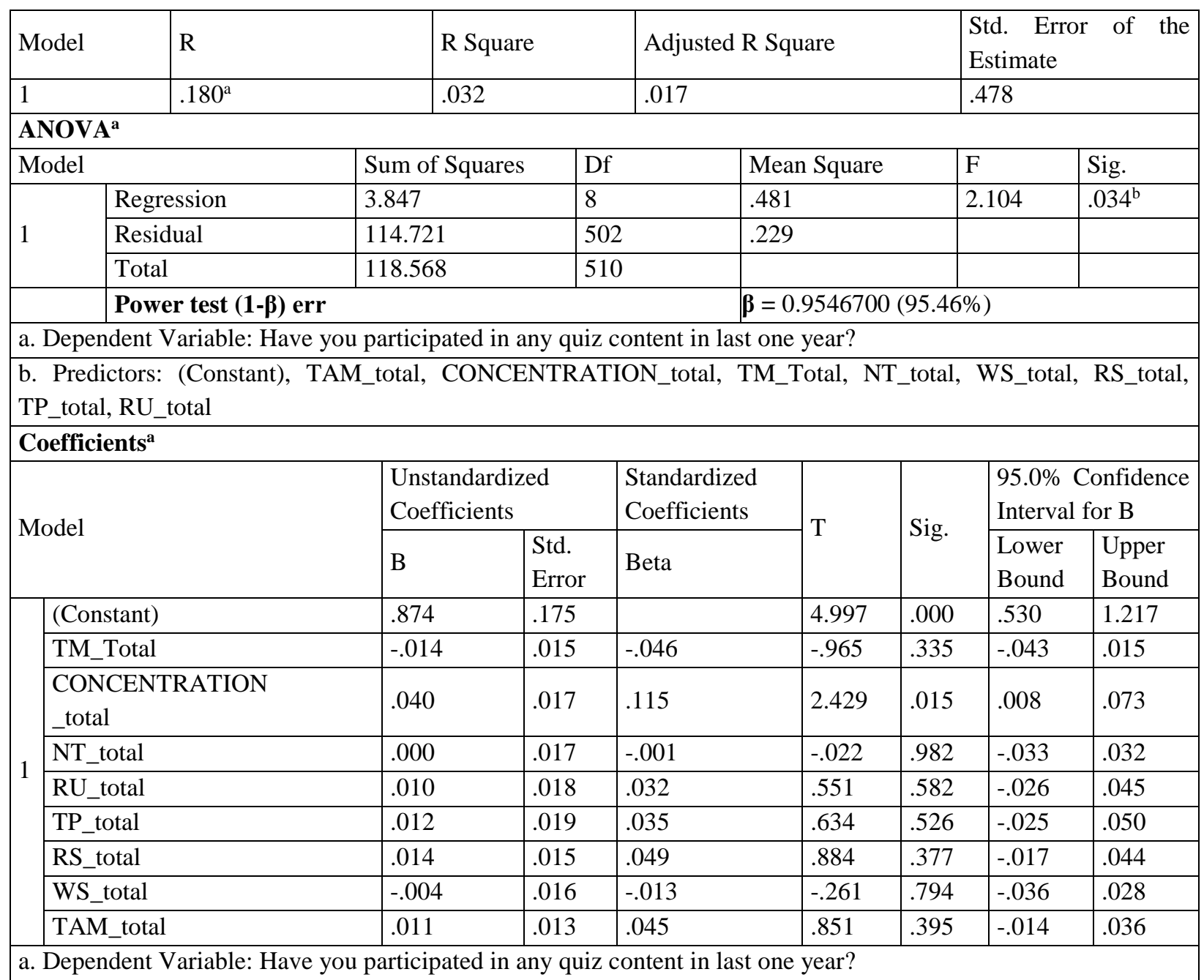

Source: field survey 2014.

The data of regression analysis showed that there was no significant contribution of study habit to determine the practice of participating in the quiz content. The regression analysis on all eight types of study habits were found significant at $\mathrm{p}$-value $\leq 0.05$ (.034), at $\mathrm{F}=2.104$ in practice of students in participating in quiz content. However, there was only one study habit was significant which had $p$-value $\leq 0.05$, namely concentration. Rest seven variables i.e. time management, note taking, reading understanding, Test Preparation and Test Taking, reading speed, writing skills and Test Anxiety Management were not significant with practice of students in participating in quiz content since the $\mathrm{p}$-value of each was $.335, .982, .582, .526, .377, .794$ and .395 respectively. It was found that there was only one variable, namely concentration had impact on the practice of students in participating in quiz content. 


\section{Study habit and participation in folk songs competition}

The regression analysis between the study habit and participation in folk songs competition found that the $\mathrm{R}^{2}$ value is .011 which means that the study variables (Time management, concentration, Note Taking, Reading Understanding, Test Preparation and Test Taking, Reading Speed, Writing Skills, Test Anxiety Management) only explain 1\% of the variation in the practice of participation in folk songs competition (dependent variable). The adjusted $\mathrm{R}^{2}$ value is -.005 which means that the different study habit had negative contribution on practice of students in participating in folk songs competition.

Table 4: Regression analysis of study habit and participation in folk songs competition

\begin{tabular}{|l|l|l|l|l|}
\hline \multicolumn{2}{|l|}{ Model Summary } & R Square & Adjusted R Square & $\begin{array}{l}\text { Std. Error of the } \\
\text { Estimate }\end{array}$ \\
\hline 1 & $\mathrm{R}$ & .011 & -.005 & .474 \\
\hline
\end{tabular}

a. Predictors: (Constant), TAM_total, CONCENTRATION_total, TM_Total, NT_total, WS_total, RS_total, TP_total, RU_total

\section{ANOVA $^{\mathrm{a}}$}

\begin{tabular}{|c|c|c|c|c|c|c|}
\hline \multicolumn{2}{|c|}{ Model } & Sum of Squares & Df & Mean Square & $\mathrm{F}$ & Sig. \\
\hline \multirow{3}{*}{1} & Regression & 1.278 & 8 & .160 & .711 & $.682^{\mathrm{b}}$ \\
\hline & Residual & 112.827 & 502 & .225 & & \\
\hline & Total & 114.106 & 510 & & & \\
\hline
\end{tabular}

a. Dependent Variable: Have you participated in any folk song competition in last one year?

b. Predictors: (Constant), TAM_total, CONCENTRATION_total, TM_Total, NT_total, WS_total, RS_total, TP_total, RU_total

\section{Coefficients $^{\mathbf{a}}$}

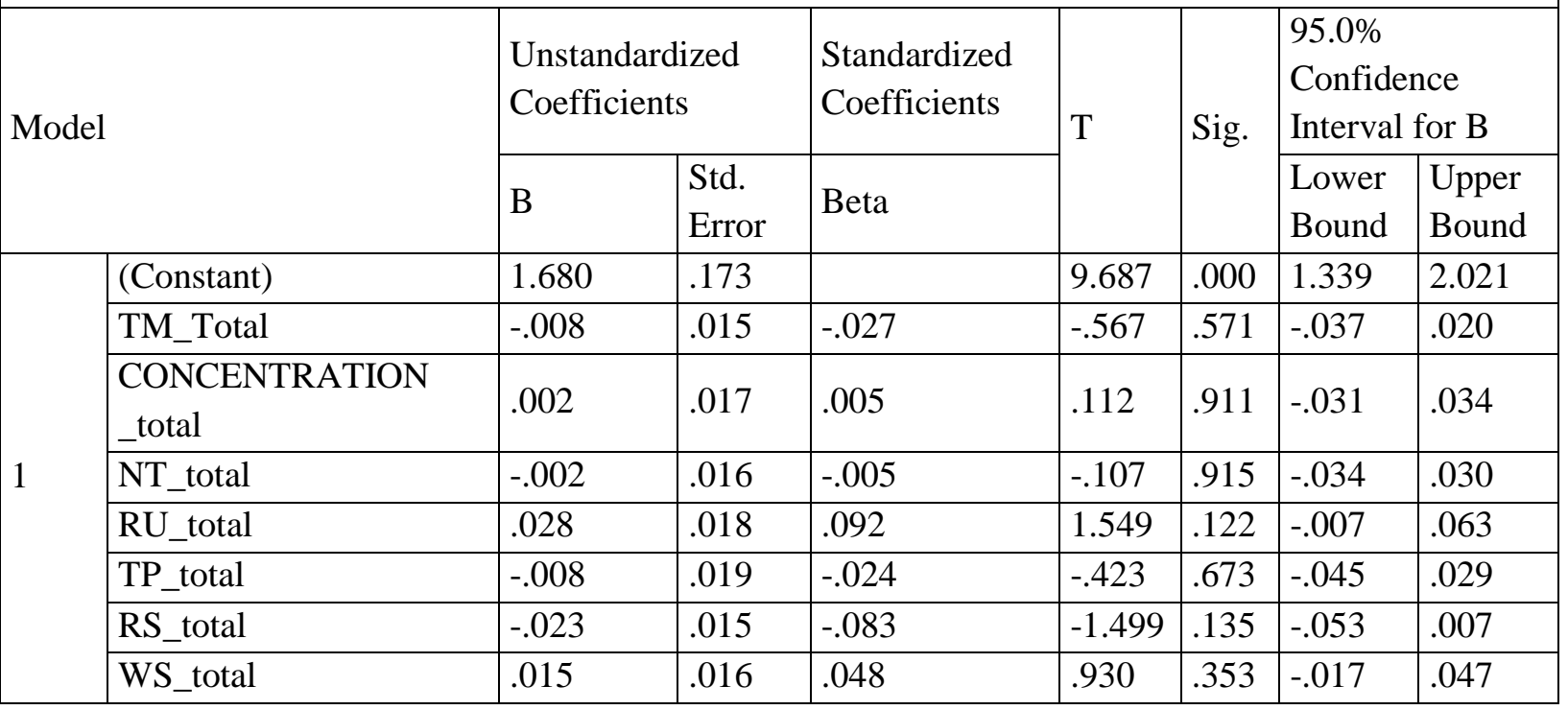




\begin{tabular}{|l|l|l|l|l|l|l|l|l|}
\hline & TAM_total & -.002 & .013 & -.008 & -.157 & .876 & -.027 & .023 \\
\hline
\end{tabular}

Source: field survey 2014.

The regression analysis on all eight types of study habits were found not significant at $\mathrm{p} \leq 0.05$ (.682), at $\mathrm{F}=.711$ in practice of students in participating in folk songs competition. There was no significant effect of any study habit on practice of students in participating in folk songs competition.

\section{Study habit and participation in speech competition}

The regression analysis between the study habit and participation in speech competition found that the $\mathrm{R}^{2}$ value is .041 which means that the study variables (Time management, concentration, Note Taking, Reading Understanding, Test Preparation and Test Taking, Reading Speed, Writing Skills, Test Anxiety Management) only explain 4\% of the variation in the practice of participation in speech competition(dependent variable). The adjusted $\mathrm{R}^{2}$ value is .026 which means that the different study habit had contributed only $2 \%$ on practice of students in participating in speech competition.

Table 5: Regression analysis of study habit and participation in speech competition

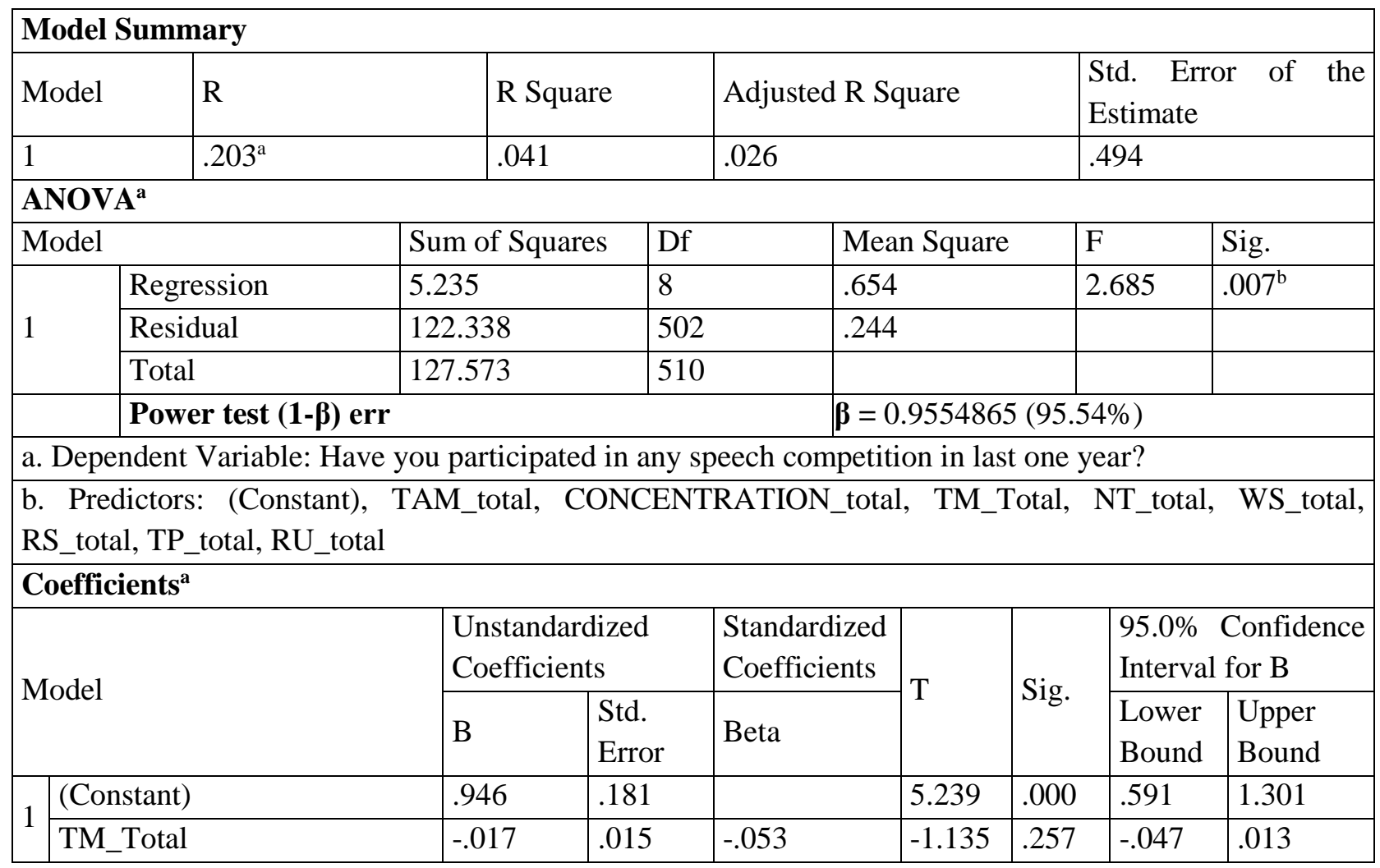




\begin{tabular}{|c|c|c|c|c|c|c|c|}
\hline $\begin{array}{l}\text { CONCENTRATION } \\
\text { total }\end{array}$ & .035 & .017 & .097 & 2.060 & .040 & .002 & .069 \\
\hline NT_total & -.004 & .017 & -.012 & -.235 & .814 & -.038 & .030 \\
\hline RU_total & .004 & .019 & .014 & .232 & .817 & -.032 & .041 \\
\hline TP_total & .000 & .020 & -.001 & -.020 & .984 & -.039 & .038 \\
\hline RS_total & .026 & .016 & .091 & 1.652 & .099 & -.005 & .058 \\
\hline WS_total & .002 & .017 & .007 & .147 & .883 & -.031 & .035 \\
\hline TAM_total & .025 & .013 & .100 & 1.886 & .060 & -.001 & .051 \\
\hline
\end{tabular}

Source: field survey 2014.

The regression analysis on all eight types of study habits were found significant at $\mathrm{p} \leq 0.05$ (.007), at $\mathrm{F}=2.685$ in practice of students in participating in speech competition. However, there was only one study habit was significant which had p-value $\leq 0.05$, namely concentration. Rest seven variables i.e. time management, note taking, reading understanding, Test Preparation and Test Taking, reading speed, writing skills and Test Anxiety Management were not significant with practice of students in participating in quiz content since the p-value of each was $.257, .814, .817$, $.984, .099, .883$ and .060 respectively. It was found that there was only one variable, namely concentration had impact on the practice of students in participating in speech competition.

Students reported that teachers should encourage the students to participate in different types of extra activities. Teachers should be responsible to make the active participation of students in quiz context, speech competition, folk song competition and sports and game. They pointed out the qualities of teachers to ensure the students' achievements.

\section{Study habit and wining any prize from schools or others}

The study had done regression analysis between the study habit and participation in speech competition to explore the effect of study habit on student achievement in extra curriculum activities; like wining any prize from own schools or others.

Table 6: Regression analysis of study habit and wining any prize from schools

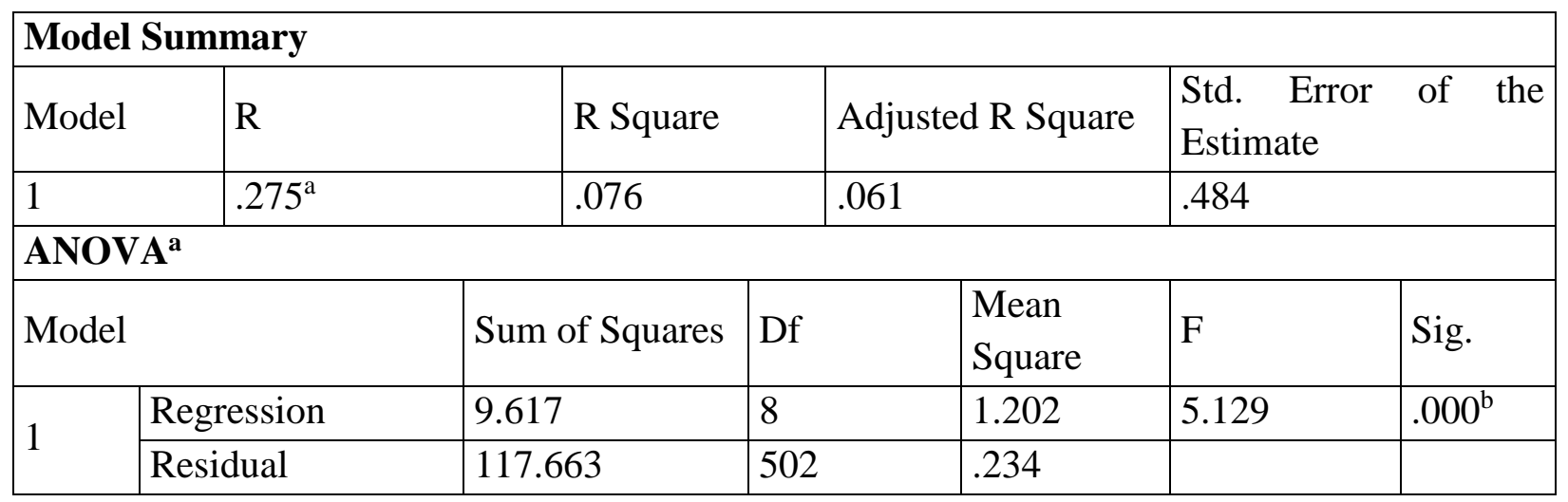




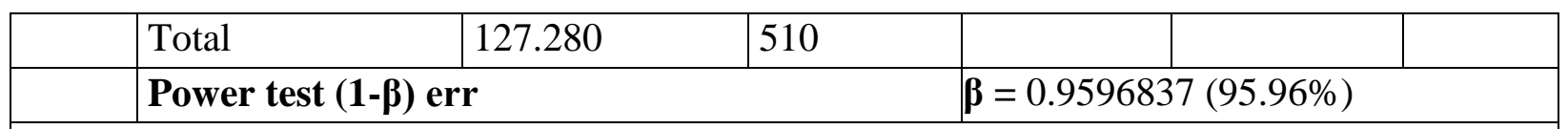

a. Dependent Variable: Have you received any prize from school or any other organizations by performing your talent-ship in last one year?

b. Predictors: (Constant), TAM_total, CONCENTRATION_total, TM_Total, NT_total, WS_total, RS_total, TP_total, RU_total

\begin{tabular}{|c|c|c|c|c|c|c|c|}
\hline \multicolumn{8}{|c|}{ Coefficients $^{a}$} \\
\hline \multirow[t]{2}{*}{ Model } & \multicolumn{2}{|c|}{$\begin{array}{l}\text { Unstandardized } \\
\text { Coefficients }\end{array}$} & \multirow{2}{*}{\begin{tabular}{|l}
$\begin{array}{l}\text { Standardize } \\
\mathrm{d} \\
\text { Coefficients }\end{array}$ \\
Beta
\end{tabular}} & \multirow[t]{2}{*}{$\mathrm{T}$} & \multirow[t]{2}{*}{ Sig. } & \multicolumn{2}{|c|}{\begin{tabular}{|l|}
$95.0 \%$ \\
Confidence \\
Interval for B
\end{tabular}} \\
\hline & B & $\begin{array}{l}\text { Std. } \\
\text { Error }\end{array}$ & & & & $\begin{array}{l}\text { Lower } \\
\text { Bound }\end{array}$ & $\begin{array}{l}\text { Upper } \\
\text { Bound }\end{array}$ \\
\hline & .767 & .177 & & 4.333 & .000 & .419 & 1.115 \\
\hline & -.008 & .015 & -.026 & -.563 & .574 & -.038 & .021 \\
\hline & .009 & .017 & .026 & .554 & .580 & -.024 & .043 \\
\hline & .034 & .017 & .102 & 2.057 & .040 & .002 & .067 \\
\hline 1 & .018 & .018 & .055 & .960 & .337 & -.018 & .053 \\
\hline & -.027 & .019 & -.075 & -1.387 & .166 & -.065 & .011 \\
\hline & -.010 & .016 & -.035 & -.646 & .519 & -.041 & .021 \\
\hline & .047 & .016 & .142 & 2.843 & .005 & .014 & 0.079 \\
\hline & .035 & .013 & .138 & 2.650 & .008 & .009 & .060 \\
\hline
\end{tabular}

a. Dependent Variable: Have you received any prize from school or any other organizations by performing your talent-ship in last one year?

Source: field survey 2014.

The analysis found that the $\mathrm{R}^{2}$ value is .076 which means that the study variables (Time management, concentration, Note Taking, Reading Understanding, Test Preparation and Test Taking, Reading Speed, Writing Skills, Test Anxiety Management) only explain 7\% of the variation in wining any prize from school or other organizations (dependent variable). The adjusted $\mathrm{R}^{2}$ value is .061 which means that the different study habit had contributed only $6 \%$ on winning any prize from schools or others.

The regression analysis on all eight types of study habits were found significant at $\mathrm{p} \leq 0.05$ (.000), at $\mathrm{F}=5.129$ in situation of winning prize from school or others. However, there was only three study habit was significant which had p-value $\leq 0.05$, namely note taking, writing skills and Test Anxiety Management. Rest five variables i.e. time management, concentration, , reading understanding, Test Preparation and Test Taking, and reading speed, were not significant with situation of students in winning prize from schools and other since the p-value of each was .574, $.580, .337, .166$ and .519 respectively. 
It was found that there was three variable, namely note taking, writing skills and Test Anxiety Management had impact on the situation of students in winning prize from schools and others. From the qualitative discussion with the students, it was found that very few students reported their prize got from the different games or academic achievements.

\section{Study habit and interaction with teachers}

Achievement of students can be measured from the other extra curriculum activities also. how students interacts with the teachers, peers, guardians and others clearly indicates the quality of their schooling so the study had asked students about their interactions practices with teachers. The study also identified the effect of study habit on the students' interaction practices with their schools' teachers. The regression analysis found that the $\mathrm{R}^{2}$ value is .042 which means that the study variables (Time management, concentration, Note Taking, Reading Understanding, Test Preparation and Test Taking, Reading Speed, Writing Skills, Test Anxiety Management) only explain $4 \%$ of the variation in students' practices of interaction with their teachers(dependent variable). The adjusted $\mathrm{R}^{2}$ value is .026 which means that the different study habit had contributed only $2 \%$ on students' interaction with their school teachers. There was $98 \%$ contribution from the other variables than these tested study habit.

Table 7: Regression analysis of study habit and interaction with teachers

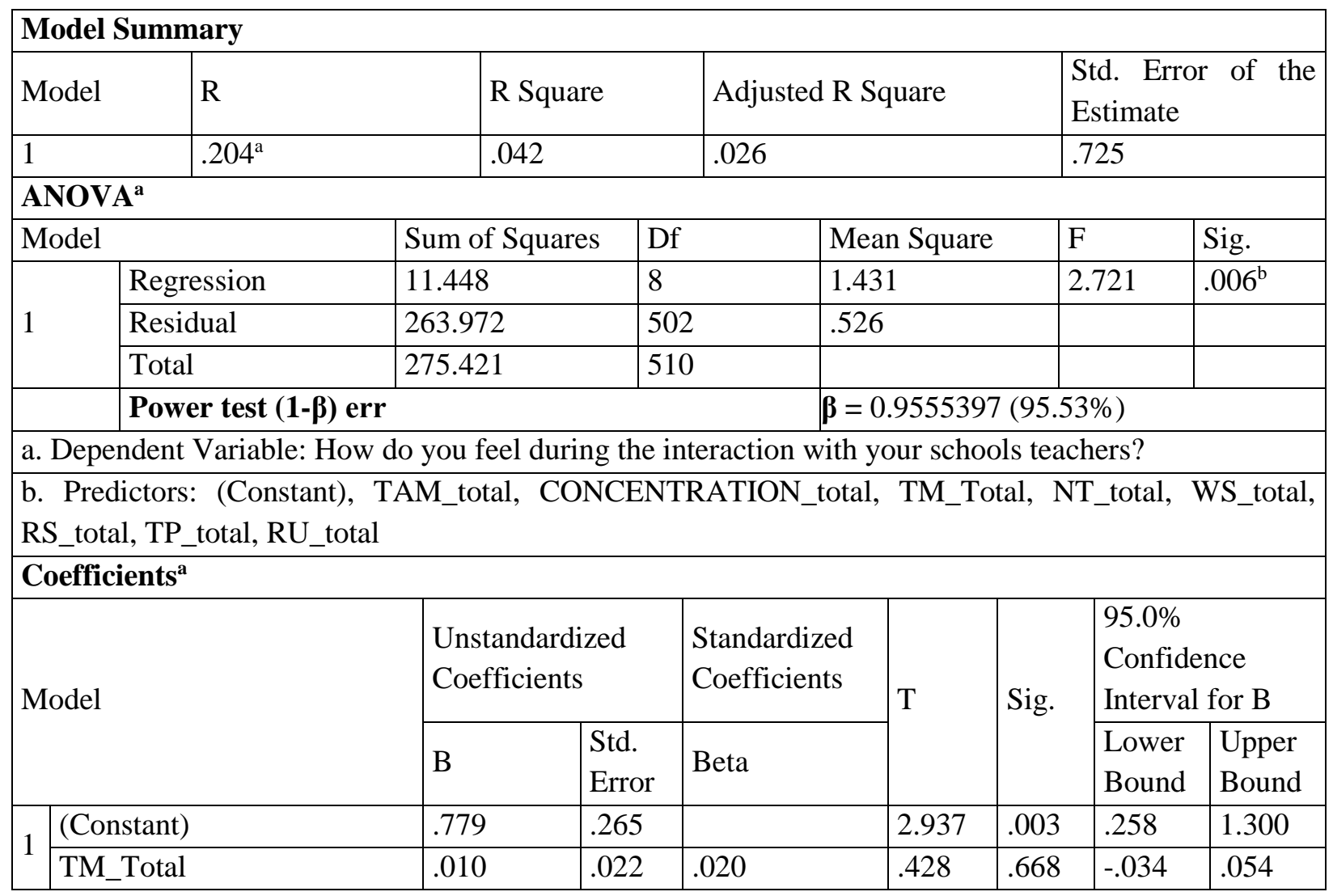




\begin{tabular}{|l|l|l|l|l|l|l|l|}
\hline $\begin{array}{l}\text { CONCENTRATION } \\
\text { total }\end{array}$ & .004 & .025 & .007 & .147 & .883 & -.046 & .053 \\
\hline NT_total & .051 & .025 & .102 & 2.030 & .043 & .002 & .100 \\
\hline RU_total & .035 & .027 & .075 & 1.282 & .201 & -.019 & .089 \\
\hline TP_total & .004 & .029 & .008 & .143 & .886 & -.053 & .061 \\
\hline RS_total & -.046 & .024 & -.108 & -1.968 & .050 & -.092 & .000 \\
\hline WS_total & .024 & .025 & .049 & .959 & .338 & -.025 & .072 \\
\hline TAM_total & .031 & .020 & .083 & 1.564 & .118 & -.008 & .069 \\
\hline
\end{tabular}

Source: field survey 2014.

The regression analysis on all eight types of study habits were found significant at $\mathrm{p} \leq 0.05$ (.006), at $\mathrm{F}=2.721$ in students' interaction with their school's teachers. However, there was only two study habit was significant which had p-value $\leq 0.05$, namely note taking and reading speed. Rest six variables i.e. time management, concentration, reading understanding, Test Preparation and Test Taking, writing skills and Test Anxiety Management were not significant with situation of students in winning prize from schools and other since the p-value of each was $.668, .883, .201$, $.886, .338$ and .118 respectively. It was found that there were only two variables, namely note taking and reading speed had impact on the practice of students' interaction with their school's teachers.

The statistical analysis of test of power of hypothesis found that there is $95.53 \%$ chance correctly rejecting the $\mathrm{H} 0$ with 511 respondents regarding the study habit and interaction with teachers.

\section{CONCLUSION}

The study found that the practices of study habit are directly related to the academic achievements. Social background of the students, their family support and the desire of student labor also determine their academic success. Poor performance will shows the poor result. The study found the significant effect of study habit on current position of student in class, expected position in SLC result, quiz contest, speech competition, out of school activities and interaction with teacher. The effect of study habit was not more than $8 \%$ in any types of achievements. Study habit was not related with the folk song competition because there is no subject related to the music; singing a song. The result shows the need of significant improvement in study habit. The teacher and guardians should be aware on the study habit along with the students. So, public and private both schools' management should plan some orientation and training program for teacher to train on the skill of study habit.

\section{BIBLIOGRAPHY}

Kuncel, M. C. (2008). Study Habits, Skills, and Attitudes - The Third Pillar Supporting Collegiate Academic Performance. University at Albany, USA. 
ISSN: 2362-1303 (Paper) | eISSN: 2362-1311(Online)

Lionel Page, L. L. (2006). Aspiration levels and educational choices - an experimental study . London : University of Westminster.

MOHAMED, A. R. (2004). Academic Performance, Educational and Occupational Aspirations of Technical Secondary School Students. Pertanika 1. Soc. Sci. \& Hum. , 12(1), 31-43.

Olatoye, R. A. (2009). Study Habit, Self-Concept and Science Achievement of Public and Private Junior Secondary School Students in Ogun State, Nigeria. An International MultiDisciplinary Journal, Ethiopia, 3(4), 492-506.

Patmalniece, M. (2011). Toward understanding of educational aspirations and expectations. The Netherlands: Tilburg School of Economics and Management.

Worsley, A. (2002). Nutrition knowledge and food consumption: can nutrition knowledge change food behaviour? . Asia Pacific J Clin Nutrition, 579-585. 